$$
\begin{aligned}
& \text { Pontifícia Universidade Católica } \\
& \text { DO RIO DE JANEIRO }
\end{aligned}
$$

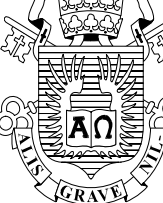

Sandra Regina Saldanha Queiroz

Adoção tardia:

a construção de uma nova história de vida

\author{
Dissertação de Mestrado
}

Dissertação apresentada como requisito parcial para obtenção do grau de Mestre pelo Programa de Pósgraduação em Psicologia do Departamento de Psicologia da PUC-Rio.

Orientadora: Profa. Terezinha Féres-Carneiro 


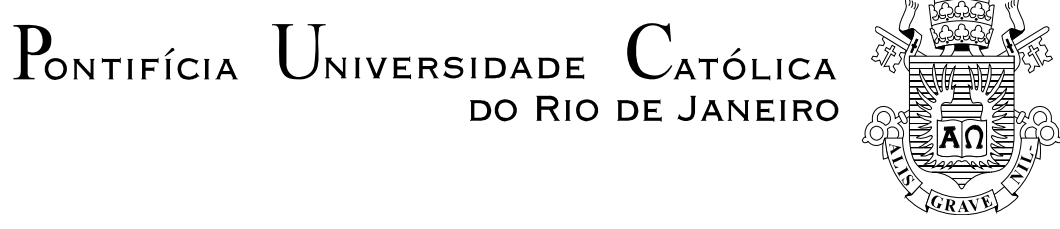

Sandra Regina Saldanha Queiroz

\title{
Adoção tardia: \\ a construção de uma nova história de vida
}

\begin{abstract}
Dissertação apresentada como requisito parcial para obtenção do grau de Mestre pelo Programa de Pós-Graduação em Psicologia Clínica do Departamento de Psicologia do Centro de Teologia e Ciências Humanas da PUC-Rio. Aprovada pela Comissão Examinadora abaixo assinada.
\end{abstract}

Profa. Terezinha Féres Carneiro

Orientadora

Departamento de Psicologia - PUC-Rio

Profa. Lidia Levy de Alvarenga Departamento de Psicologia - PUC-Rio

Profa. Monica de Vasconcellos Dias Universidade Veiga de Almeida - UVA

Profa. Denise Berruezo Portinari Coordenadora Setorial de Pós-Graduação

e Pesquisa do Centro de Teologia e Ciências Humanas - PUC-Rio

Rio de Janeiro, /2011. 
Todos os direitos reservados. É proibida a reprodução total ou parcial do trabalho sem autorização da autora, da orientadora e da universidade.

\section{Sandra Regina Saldanha Queiroz}

Psicóloga formada pela Universidade Gama Filho, Rio. Especialista em dependência Química, Terapeuta de casal e familia pelo Delphos e Especialista em Psicanálise pela Universidade Gamam Filho

\section{Ficha Catalográfica}

Queiroz, Sandra Regina Saldanha

Adoção tardia : a construção de uma nova história de vida / Sandra Regina Saldanha Queiroz ; orientadora: Terezinha Féres-Carneiro. - 2011.

90 f. ; $30 \mathrm{~cm}$

Dissertação (mestrado) - Pontifícia Universidade Católica do Rio de Janeiro, Departamento de Psicologia, 2011.

Inclui bibliografia

1. Psicologia - Teses. 2. Adoção tardia. 3. Pais adotivos. 4. Filhos adotivos. 5. Vínculo afetivo. I. Carneiro, Terezinha Féres. II. Pontifícia Universidade Católica do Rio de Janeiro. Departamento de Psicologia. III. Título. 
Dedico este trabalho a minha mãe, Maria Helena Barbosa Saldanha, viva dentro de mim e ao meu pai Jalbas Campos Saldanha, que sempre demonstraram amor e carinho pela minha existência; ao meu marido, que me proporcionou a oportunidade de aprender o valor da persistência e da busca incassável dos objetivos almejados, a minha filha Desirée, que sempre me incentivou no meu crescimento intelectual, ao meu filho Lohran que participou com afeto desta trajetória, a minha filha Blanche, pela ternura e paciência que sempre demonstrou por mim, ao meu filho Fabien, pelo seu amor e carinho ao testemunhar minhas angústias e preocupações, e a minha filha Julienne, que chegou trazendo-me a diposição para realizar este trabalho. 


\section{Agradecimentos}

À professora Terezinha Féres-Carneiro, pela disponibilidade ao orientar essa pesquisa, ensejando-me uma grande oportunidade de crescimento profissional e humano.

À professora e psicanalista Luiza Atalia Fontes, fundamental no meu autoconhecimento, grande incentivadora para que eu vencesse mais este desafio.

Aos professores da PUC-RIO, Andréa Seixas, Ana Maria Nicollaci e Lídia Levy, por sua dedicação e ensinamentos. À Marcelina e Vera, por sua incansável paciência e atenção.

À professora Eva Maria Fernandes Ferreira Bressan, por sua disponibilidade e pela importante contribuição na elaboração deste trabalho.

À CAPES, pelo incentivo financeiro durante todo este estudo.

Às minhas amigas Ana Paula, Silvana, Beatrice e Virginia, mãos amigas na conclusão deste trabalho.

Às minhas amigas Erika, Helena e Paula, partícipes das dores e alegrias de sermos mestrandas.

Aos grupos de apoio à adoção Quintal de Ana e Rosas, cujos dedicados participantes Lula, Fabiana e Silvania abriram-me as portas e o coração para compreender melhor o uinverso da adoção.

A todos mais que, direta ou indiretamente, fizeram parte desta jornada e, embora não estejam citados formalmente, contribuíram para a realização deste estudo. Muito obrigada a todos. 


\section{Resumo}

Queiroz, Sandra Regina Saldanha; Féres-Carneiro, Therezinha (Orientadora). Adoção tardia: a construção de uma nova história de vida. Rio de Janeiro, 90p. Dissertação de Mestrado - Departamento de Psicologia, Pontifícia Universidade Católica do Rio de Janeiro.

A adoção tardia de uma criança é um processo complexo que suscita sentimentos ambíguos, tais como amor, desconfiança, preconceito, insegurança, medo, frustração e realização plena. O presente trabalho tem como objetivo investigar as implicações envolvidas no processo da adoção tardia, tanto no que diz respeito a pais adotantes quanto a crianças adotivas. A coleta de dados para a elaboração dessa pesquisa foi feita com a participação de três mães adotantes, três pais adotantes e três filhos adotivos, no estado do Rio de Janeiro, entre os anos de 2009 e 2010. Os filhos adotivos tinham entre 6 e 14 anos na época de sua adoção. Foram realizadas entrevistas semi-estruturadas com as mães, os pais e os filhos, não havendo entre os participantes nenhuma relação de parentesco. A partir da técnica de análise de conteúdo, os dados foram agrupados em 5 categorias, assim nomeadas: 1) a motivação dos pais para adotar; 2) o preconceito na adoção; 3) o processo jurídico na adoção; 4) a importância dos grupos à adoção; 5) a criança na nova família. Constatou-se que, em todos os casos de adoção, a motivação preponderante foi a esterilidade de um dos membros do casal. Em princípio, todos desejavam adotar um bebê recém-nascido e, no decorrer do processo, devido à dificuldade de encontrar crianças com esse perfil, optaram pela adoção de crianças maiores. A esperança de uma realização plena que envolve o primeiro momento na busca de uma adoção sofre um impacto que, diante das dificuldades que se apresentam, assim como diante da criança real, muitas vezes frustra essa expectativa inicial. A maioria dos entrevistados, declarou ter recebido o apoio de toda a família na decisão de adotar um filho, ainda que, tenha havido manifestação de preconceito por pessoas de seu meio social. Conclui-se que, para os pais e mães adotantes assim como para os filhos adotivos, o estabelecimento do vínculo afetivo-familiar não ocorre de imediato. Há que se percorrer um longo caminho buscando constituir um futuro sólido nessa relação sem, contudo, esquecer-se do passado da criança que não pode ser apagado. A verdade é o alicerce sobre o qual se erguerá uma relação sólida entre pais e filhos. Os grupos de apoio funcionam como elemento facilitador para a construção dessa relação.

\section{Palavras-chave}

Adoção tardia, pais adotivos, filhos adotivos, vínculo afetivo. 


\section{Abstract}

Queiroz, Sandra Regina Saldanha; Féres-Carneiro, Therezinha (Advisor). Late Adption: building a new life history. Rio de Janeiro, 90p. MSc. Dissertation. Departamento de Psicologia, Pontifícia Universidade Católica do Rio de Janeiro.

The late adoption of child is a complex process that raises ambiguous feeling, such as love, mistrust, prejudice, insecurity, fear, frustration and full realization. The aim of this work is to investigate implications involved in process of late adoption, in relation to the adoption parents and to the adoption children. The data saved for the elaboration of the research has been collected with the participation of three adopting mothers, three adopting fathers, threes adopting children in the state of Rio de Janeiro, between 2009 and 2010. The adopted children were between 6 and 14 years old at the time of their adoption. Semi structured interviews with the mothers, fathers and children were held, not existing any parental relationships among the participants. Starting from the technique used to analyze the contents the contents of the research, the data was grouped into 5 categories, so named: 1) the parent's motivation to adopt; 2) The prejudice in adoption; 3) the legal process; 4) the importance of the groups to the adoption; 5) the child in the new family. It has been found that I all the adoption cases the most frequent motivation was the sterility of one member of the couple. At the beginning all wanted to adopt a newborn baby and, as the process went by, due to the difficulty to find a child who would meet that profile, then chose to adopt older children the hope for the full realization that involves the first moments in the search for adoption suffers an impact that, before the difficulties that arise and also before the real child many times frustrates the initial expectation. Most of the interviewees declared that they had received the support of the whole family by the time of their decision to adopt a child. Although, there was some prejudice from people in their social circle. The conclusion, for the adoption fathers and mothers as well as the adopted children, was that the establishment of the family bonds does not occur immediately. It's a long way to establish a safe future for that relationship. Not forgetting though the past of the child, that can not be ignored. The truth is the foundation above all and children will be raised. The support groups work as facilitators for the construction of that relationship.

\section{Keywords}

Late adoption, adopting parents, adopted children, family bonds. 


\section{Sumário}

$\begin{array}{lr}\text { 1. Introdução } & 9\end{array}$

2. A adoção $\quad 15$

2.1. Evolução histórica $\quad 15$

2.2. Conceito de adoção 20

2.3. Adoção tardia 23

2.4. Preconceitos na adoção 27

2.5. Mitos e crenças na adoção 31

3. A família $\quad 34$

3.1. Da parentalidade à filiação 34

3.2. A relação mãe-bebê e o desenvolvimento emocional da criança 39

3.3. Os pais adotantes $\quad 47$

3.4. A criança adotiva $\quad 55$

4. Metodologia $\quad 63$

4.1. Participantes 63

4.2. Procedimento 64

4.3. Análise dos dados 65

5. Considerações finais $\quad \mathbf{8 0}$

Referências bibliográficas $\quad 84$ 